\title{
THE CIVIL CODE OF JAPAN COMPARED WITH THE FRENCH CIVIL CODE.
}

By Kazuo Hatoyama, LL.D.

William L. Storrs, Lecturer in the Yale Law School, I901-2.

I.

I propose in these lectures to treat of the reasons that led to the adoption of the Japanese Civil Code; to give a brief sketch of the history of its compilation, and then to compare it with the French Civil Code making at the same time occasional references to the German Civil Code. In this study of comparative legislation I shall not attempt to examine the fourth and fifth Books on Family Relations and Succession as they contain many features peculiar to Japan which can not be explained without fully going into the historical development of Japanese institutions.

The first three Books of the Code, namely: Book I, General Provisions ; Book II, Rights in Rem; and Book III, Rights in Personam, were promulgated on the 24th of April, I896, and the remaining two Books were promulgated two years later. The whole Code thus enacted went into operation on the I6th of July, I898.

I will mention tha two principal causes that led to the adoption of the Civil Code.

The first and most important arose from the social and political reforms effected subsequent to the restoration of the Emperor to actual power in 1868 . The feudal system, which was, until then, in full play, created a sort of imperium in imperio within the localities occupied by the Dymios, of whom there were about three hundred, large and small. Each Dymio was almost a sovereign in his own province. He had his own retainers who owed direct and personal fealty to him, but whose allegiance to the Shogun was indirect. He exercised both civil and criminal jurisdiction within his district. $\mathrm{He}$ even issued paper currency, the circulation of which was, of course, limited to his jurisdiction. The apparent result of this kind of political system was the want of unity considered from a national standpoint. The system was, however, swept away by the revolu- 
tion of 1868 and the whole country was brought under the direct control of the central government. The four hereditary classes, namely, the Samurai, or soldiers, the agriculturists, the artisans, and the merchants were abolished. They all became equal in the eye of the law, and could freely choose their business or profession. The family system, which had been until then religiously preserved, was weakened, and in many instances the individual members of families were held directly responsible to the government. For criminal acts they were held personally liable, and so also for duties imposed by the conscription laws, while at the same time their capacity to hold property and to transact business independently of the head of the family was recognized. The improvements in maritime and land communication gave strong impetus to commercial enterprises and encouraged the formation of companies. Higher education, which had been almost the monopoly of the Samurai and the clergy, became the common right of all. A system of national education was adopted whereby all alike and without the least distinction could avail of the opportunities afforded. Courts of various grades were established to render equal justice to all. To meet exigencies created by these social and political changes, tentative and fragmentary legislation was resorted to. The fact that legislation of this kind could not keep pace with the wants of the rapidly progressing people is well illustrated by Edict No. IO3 of the eighth year of Meiji, issued by the Daijokwan (Council of State) in the form of instructions to the judges, which had the effect of law until the Code came into operation. The instructions were that judges were to render justice according to law where there was an express enactment to be applied. When there was no such enactment they were to decide according to custom. In the absence of either law or custom, they were to decide according to just principles. What those just principles were, was left entirely to the discretion of the judges. It is curious to recall, in this connnection, that when the introduction of foreign elements necessitated the creation of the office of Praetor Perigrinus in Rome, the office was established without any definition of the principles to be applied in the Praetorian Courts. The Praetors, therefore, were obliged to render judgments according to what they believed to be the principles of justice. In the course of time a system of jurisprudence was developed from their edicts and judgments. The Japanese judges, in seeking just principles to be applied to cases which were entirely novel, examined the jurisprudence of Europe and America, and, in 
thus appealing to the various occidental systems, they endeavored to eliminate those features of law which were accidental or merely historically important in particular countries, and selected the legal principles which might be said to be absolute and common to all. Of course all judges could not be expected to do this, but they were ably assisted by the researches of the advocates who now formed an influential body, a large number being well versed in jurisprudence. A system of jurisprudence would, in the course of time, have been developed in this manner in Japan, just as the Praetorian law was developed in Rome, but the immediate wants of society arising out of social, economical, and political revolutions had to be supplied and the need of a systematic and complete code was urgently felt and recognized.

The second cause that led to the adoption of the Civil Code was due to the earnest desire of the Japanese people to resume the civil and criminal jurisdiction over the subjects and citizens of the sixteen Treaty Powers of Europe and America. We had ceded such jurisdiction by our earlier treaties and a peculiar system termed "extra-territoriality,"-not of ambassadors and other privileged persons, but of missionaries, merchants and in some instances perhaps adventurers,-which existed only in the East, as for example in Turkey, China, Corea, etc., had been also established in Japan. Practically, as the number of European and American residents in Japan was very small, I do not think it worked any serious harm, but, as a matter of principle, it was strongly objectionable to the highly sensitive Japanese. In our several attempts to recover the ceded privilege we were met by the objection that our laws were incomplete. I do not myself think that this objection was tenable, since no one has a right to question the adequacy or the completeness of the laws of the country to which he resorts. But as I have stated before, actually our laws were not adequate to the exigencies of the time. Therefore, in the first draft of the treaty revision proposed by the Japanese Government, a clause was inserted to the effect that the Japanese Codes would be compiled and put in operation before the new treaties should go into effect. In the final draft, that is, in the existing treaties, this clause was not inserted in the body of the treaties, but official communications to the same purport were made by the Japanese Plenipotentiaries to the respective governments.

These are the two principal causes that led to the compilation and adoption of the Japanese Codes.

Codification is never a question of the form of the laws only. It is more or less a question of both $f$ :m and substance. In a coun- 
try where the laws are comparatively uniform and equally developed in all parts of the country it is more a question of form and arrangement; but even then, codification means changes of substance as well as of form. For example, the Negotiable Instruments Law framed and recommended by the Commissioners in 1896 contains a large number of changes of the law of bills and notes; while, as was the case in France when the country was divided into two parts, one of which was chiefly governed by the Roman Law and the other by unwritten laws and customs having the force of law, codification was equally a question of form and of substance. So also, and more emphatically in Japan, where the country, formerly divided into numerous Dymioates, was brought under the direct control of a supreme central government; and where a nation, previously contentedly leading a self-contained peaceful Asiatic existence, with little or no knowledge of the outside world, was suddenly brought into contact with Western nations and was aroused, as it were, from its lethargy and obliged to prepare itself to enter into the family of nations, codification of the laws was more a question of substance than of form.

The work of codification in Japan dates as far back as the third year of Meiji (1870) when a Bureau was established for the investigation of institutions. In 1878 a draft was submitted by the bureau to the Government, but this was not adopted. In I880 Prof. Boissonade, an eminent French jurist then in the service of the Japanese Government, was asked to make a new draft. The next year he completed his work which was submitted to a committee of gentlemen composed of members of the Genroin (the only deliberative council then existing, its members being appointed by the Emperor) and of the Bench. The committee made their report in 1888 and it was sent to the Genroin. The report was approved by that Council and on the 27th of March, I890, under Act 28, Book II, "Property in General ;" Book III, "The Means by which Property is Acquired ;" Book IV, "Security of Rights in Personam;" and Book $\mathrm{V}$, "Evidence and Prescription," were published. It is well to observe that these laws were based on the project submitted by Prof. Boissonade, while the remaining portions of the Code were drafted exclusively by Japanese jurists. In October of the same year, under Act 98, Book I, "Persons," and the "Law of Succession," which was to form a part of Book III, were published and the whole of the Code thus completed was to go into operation from the first day of January, I893. Upon its publication the Code became a topic of earnest and sincere discussion. Public opinion differed widely. 
Meantime the Constitution had been granted in February, I889, and the Imperial Diet convoked in I890. The opponents of the Code insisted on its revision. At the session of 1892 a bill was introduced in the Lower House to postpone the operation of the Code with a view to its revision. After several warm debates the bill was passed by the Representatives. The measure was also adopted by the Upper House and the operation of the Code was in consequence postponed until the 3ist of December, I896. In March, I893, a Law Commission was established by Imperial edict. The commissioners comprised members of both Houses, professors of the Imperial University, members of the Bench and the Bar and leading merchants. Professors Hozumi, Tomii, and Ume were appointed a subcommittee to prepare a draft for the discussion of the commissioners. Although the commissioners were appointed to revise the Code of I890 they in fact recast it. In March, I896, the report of the commissioners on Book I, "General Provisions," Book II, "Rights in Rem," and Book III, "Rights in Personam," was submitted to the Diet and was adopted with a few unimportant modifications. On April 28th of the same year these books were promulgated as laws. Books IV and V on "Family Relations," and "Successions," were enacted as law under Act 9, in June, I898, the whole to go into effect on the I6th of July, 1898. This is the existing Civil Code of Japan.

\section{II.}

The Arrangement of the Code.-In the Institutes of Justinian the Roman law is arranged under three divisions: I, Jus Personarum; II, Jus Rerum; III, Jus Actionum-(Just. Inst., I Tit. 3). This classification is followed with more or less modification by the French and other continental codes. The French Civil Code is arranged in three Books. Book I, "Des personnes," treats of the enjoyment and privation of private rights, domicile, absence, marriage, divorce, paternity and filiation, minority, majority, paternal powver, guardianship, etc. Book II, "Des biens et différentes modifcations de la propriété," treats of the distinctions of movables and immovables, different species of ownership or rights of property, usufruct, use and habitation, servitude, etc. Book III, "Des différentes manières dont on acquiert la propriété," treats of succession, testaments, contracts, implied contracts and torts, marriage contracts, sale, exchange, hiring, mandates, agency, letting, suretyship, mortgage, privilege, prescription, etc. 
The Japanese Code of 1890 was arranged under the five heads mentioned in Lecture I. The draft Civil Code of New York contains four divisions:-I, Persons; II, Property; III, Obligations; IV, General Provisions relating to persons, property, and obligations.

We have made a wide departure from these precedents in the arrangement of our new Code. In Book I (General Provisions), are found Persons, Artificial or Juridical Persons, Things, Legal or Juristic Acts, Periods of Time and Prescription. In Book II (Rights in Rem), are found Possession, Ownership, Superficies, Emphyteusis, Easements, Possessory Liens, Preferential Rights (i. e. equitable liens), Pledges and Mortgages. In Book III (Rights in Personam), are treated: Ist, General Provisions applicable to rights in personam which include the subject of rights in personam, the effect of rights in personam, the rights in personam in which many parties are concerned, the assignment and the extinction of rights in personam; and, Contracts, under which head are general provisions applicable to contract, donation, sale, exchange, loans for consumption, loans for use, letting and hiring, hire of labour and services, contracts for execution of specified work, agency or mandate, deposit, association, life-annuities, and amicable arrangement; 3rd, Management of Business; 4th, Improper Profits or Unjust Enrichment; and 5th, Wrongful Acts (i. e. delicta according to Roman law). Book IV (Family Relations), contains the following -headings: Ist, General Provisions; 2nd, The Head and Members of a Family; 3 rd, Marriage and Divorce; 4 th, Parents and Children; 5th, Parental Rights; 6th, Guardianship; 7th, Family Councils; and, 8th, The Duty of Support. In Book V (Succession), are found: Ist, Succession to the Headship of a Family ; 2nd, Succession to Property ; 3rd, Acceptance and Renunciation of Succession ; 4 th, Separation of Property; 5th, Failure of Heirs; 6th, Wills; and, 7th, The Heir's Portions.

This arrangement finds its analogy in the Saxon and the German Civil Code, with the difference that in the latter Rights in Personam make the subject matter of Book II while Rights in Rem aredealt with in Book III.

It should be here noted that in the Roman Law, and the French Code fashioned after it, the laws relating to persons occupy the first and most important part of the Code, while in the Japanese Code they are placed in the fourth Book following the laws relating to property and obligations. This new distribution can not be said to be wholly without reason. In the earlier societies rights were deter- 
mined more by distinction of personal status than by contracts arising out of the exercise of the free will of persons, and property, the kinds of which were few and phases less complicated, was comparatively less important, while the tendency of modern civilization is towards individual freedom, abolition of distinction of rights and privileges based upon difference of personal status, allowing each individual man or woman to cieternine his or her rights and duties by the exercise of his or her own free will. At the same time the growth of industry and commerce on a gigantic scale has given rise to various forms and modifications of proprietary rights unknown in past times. Hence, in the Saxon, the German, and the Japanese Codes, laws relating to property and obligations occupy the first and more important places, while laws relating to persons are relegated to secondary places.

Book I of the Japanese Code is specially devoted to general provisions common to all legal relations. This is an important deviation which finds its ample justification in the fact that the body of the law is thereby made succinct, repetitions are avoided and the work of the student is rendered easier. Laws relating to capacity, and domicile, which in the French Code come under "Des personnes," laws relating to general legal acts which in the French Code occupy a place under the heading of contracts, but which in reality relate, not to contracts alone, but to all legal acts, and finally laws relating to prescription are in the Japanese Civil Code brought together in their proper places in this division of General Provisions.

Again in the French Code rights in rem and rights in personam are not logically classified, neither do they form distinct headings, while in the Japanese Code the logical classification is strictly followed. Those portions of Book III of the French Code, which treat of such as privileges and mortgages, together with a large portion of the subject matter of Book II of the same Code, form a distinct heading in Book II of our Code.

The laws relating to artificial or (as we prefer) juridical persons are not found in the French Code, but with the growth and development of corporations and associations in modern society, a civil code without rules relating to them would hardly be complete or responsive to the requirements of the times. The French Code contains provisions which relate to public law and also to procedure. These are wisely omitted from the Japanese Code. 
III.

General Remarks.-In this lecture a few points 'of difference between the Japanese and French Codes that have a general bearing and which can better separately be treated here than under particular divisions, will be noticed.

The French Code contains redundant definitions and illustrations for which the school rooms and lecture halls are fit places, not the Civil Code. In the French Code rules springing from the same general principles are distributed in different places. This increases the volume of the laws without any corresponding advantages.

When a rule of law can be stated in general terms legislators ought no doubt to so formulate it. But the Frencl Code, not satisfied with general propositions, frequently descends to particulars. This is avoided in the Japanese Code. Every changing and progressing society produces different phases of development. If particulars are stated in a code, the code will not be responsive to new conditions. whereas a general statement of law. will enable the judiciary to apply the code to new cases by resorting to analogy.

The absurd theory of natural law, or the law of nature, which had its vogue in Europe in the I7th, I8th, and the first half of the Igth centuries, is reflected in the French Code, e. g. by the recognition of natural obligations. No such misconception influenced the minds of the framers of the Japanese Code. They were fully convinced that laws are made by human legislative agency; that all rights and duties are the creatures of law and that there are no rights not recognized by law. Hence, a so-called right which can not be legally enforced is not considered as a right in the Japanese Code.

The authors of the French Code started from the standpoint of duties, while the framers of the Japanese Code made rights the point of departure. Naturally a correlation exists between rights and duties. A legal relation may be stated from the conception of a right or the corresponding duty. It comes to the same thing. I do not mean to say that in the Japanese Code this idea is invariably adhered to, but, generally speaking, rights are made the object of legislation. The point is immaterial, but it seems to me that, broadly speaking, laws should start from the standpoint of right, while principles of morality may better be considered from the conception of duties.

(Remainder to appear in May and June issues). 